\title{
Host Range, Biological Variation, and Phylogenetic Diversity of Eutypa lata in California
}

\author{
F. P. Trouillas and W. D. Gubler
}

Department of Plant Pathology, University of California, Davis 95616.

Accepted for publication 4 June 2010.

\begin{abstract}
Trouillas, F. P., and Gubler, W. D. 2010. Host range, biological variation, and phylogenetic diversity of Eutypa lata in California. Phytopathology 100:1048-1056.

The objectives of this study were to investigate the host range of Eutypa lata in the major grape-growing regions in California and to analyze the phenotypic variation and phylogenetic diversity of E. lata isolates. Perithecia of $E$. lata were found on grapevines, in apricot, almond, cherry, apple, and pear tree orchards, and on ornamentals (oleander) and native plant species (California buckeye, big leaf maple, and willow). Multigene phylogenies of ribosomal DNA internal tran-

lata recovered from the various host plants but also revealed sequence differences among isolates. The intraspecific phylogenetic diversity of $E$. lata did not correspond to geography or source of isolation, and intraspecific groups were not consistent across the different DNA phylogenies. Significant phenotypic variation also was detected among $E$. lata isolates, including ascospore and conidium length as well as level of aggressiveness on grapevines. Pathogenicity studies proved that all isolates were infectious to grapevine, suggesting that the native vegetation surrounding vineyards can serve as inoculum sources that may constitute an important element in the epidemiology of Eutypa dieback in grapevines.
\end{abstract} scribed spacer, $\beta$-tubulin, and $R P B 2$ genes confirmed the identity of $E$.
Eutypa lata (Pers.) Tul. \& C. Tul. (syn: E. armeniacae Hansf. $\&$ M. V. Carter) (Diatrypaceae) is the pathogen responsible for a widespread and destructive fungal disease, mainly of grapevine (Vitis vinifera), apricot (Prunus armeniaca), and sweet cherry $(P$. avium), known as Eutypa dieback $(2-4,8,22,26)$. In California, Eutypa dieback constitutes one of the most common fungal canker diseases of grapevine, particularly in the North and Central Coasts and in the Sacramento and Northern San Joaquin Valleys (52). Infection normally occurs during the pruning season when fresh pruning wounds become exposed to wind-dispersed ascospores, which are released following rainfall of $\approx 2 \mathrm{~mm}$ or greater $(4,20)$. Typical symptoms of Eutypa dieback in grapevine include formation of wedge-shaped cankers in wood; death of spurs, cordons, and eventually the entire grapevine; leaf necrosis and chlorosis; and tattering as well as stunting of new shoots $(2,4,22)$. Eutypa dieback also affects yield and longevity of vineyards and usually becomes more severe as vineyards become older (25). Recently, other pathogens in the families Diatrypaceae and Botryosphaeriaceae have been associated with grapevine trunk diseases in California (50-52). Overall, grapevine trunk diseases are responsible for significant economic losses to the wine industry estimated to be up to $\$ 260$ million annually (42).

Ascospores of E. lata are the primary form of inoculum and they infect grapevines through fresh pruning wounds during periods of rainfall $(3,4,20)$. Ascospores are released from mature perithecia clustered in a black stroma embedded in decorticated wood or, sometimes, in the bark on dead trunks or branches of lignified angiosperms $(3,4)$. E. lata perithecia are thought to develop in areas with at least $350 \mathrm{~mm}$ of annual rainfall (4). Perithecia have been observed on most continents (4) and have been found on at least 88 host plant species in 28 plant families (5). Until recently in California, only a few hosts of E. lata were

Corresponding author: W. D. Gubler; E-mail address: wdgubler@ucdavis.edu

doi:10.1094/PHYTO-02-10-0040

(c) 2010 The American Phytopathological Society known (Ceanothus spp., $P$. armeniaca, $P$. avium, $P$. dulcis, $P$. virginiana var. demissa, and $V$. vinifera) $(5,7,9,21,23,26)$. The inoculum that infects grapes in the Central Valley of California was thought to originate primarily from apricot trees in the Suisun Bay area on the east end of San Francisco $(28,36)$, because perithecia had not been found on grapevines in the Central Valley. Thus, ascospores of E. lata were thought to travel long distances on air currents from coastal areas where perithecia were found $(20,28,36)$ to the interior Central Valley of California and North Coast production areas, including Napa, Sonoma, and Mendocino Counties. Additional reports of the host range of $E$. lata in California have included V. vinifera, $P$. avium, and $P$. dulcis in Sacramento, Yolo, San Joaquin, and Napa Counties (26). However, despite the previous surveys, only a few individuals among the various host species were confirmed to support formation of perithecia; therefore, their importance as sources of inoculum as well as the current distribution of the perithecial stage of E. lata remained unclear. Identifying the inoculum sources for the disease constitutes critical knowledge of disease epidemiology and may ultimately help to reduce risks of infection if these sources can be eliminated.

Little effort has been made to analyze the population structure of E. lata, including isolates from a wide range of host plants, particularly isolates originating from both cultivated and indigenous plant species. The study of DeScenzo et al. (6) suggested the occurrence in California of two species of Eutypa (E. armeniacae and $E$. lata), both capable of infecting grape. They proposed $E$. lata sensu stricto to refer to strains found predominantly on native hosts and separated it from E. armeniacae, which they referred to strains associated with cultivated hosts. Subsequent studies of the strains used by DeScenzo et al. (6) revealed that strains from native host plants in California were, indeed, Diatrype stigma (Hoffm.) Fr. (40) and the occurrence of E. lata (syn: E. armeniacae) on native hosts remained unknown.

The objectives of this study were to (i) establish the current distribution and host range of the perithecial stage of E. lata in California's main grape-growing regions, (ii) characterize the 
phenotypic and phylogenetic diversity of California population of $E$. lata, and (iii) test the pathogenicity in grapevine shoots of $E$. lata isolates collected from various host plants and regions in California.

\section{MATERIALS AND METHODS}

Surveys. During the years 2000-2002, we surveyed the main grape-producing regions of California for perithecia of E. lata. Surveys were conducted in vineyards and orchards and on native and ornamental woody plants surrounding vineyards in the counties of Napa, Sonoma, Solano, Sacramento, San Joaquin, Contra Costa, El Dorado, San Benito, Stanislaus, Merced, Fresno, Madera, Tulare, Kern, and Yolo. Plants with dead wood and dieback were checked for the presence of typical fruiting bodies of E. lata.

Isolate origin and cultivation. Isolates used in this study are presented in Table 1. E. lata isolates were obtained from perithecia on various woody host plants and from hyphae in infected wood of grapevines and apricot trees in California. Referenced isolates of E. lata and Eutypa spp. most closely related to E. lata $(1,37,40)$ were used in the phylogenetic study. These included E. lata var. aceri, E. laevata, and E. petrakii var. petrakii. Isolates obtained from perithecia were cultured using ascospores as described by Trouillas et al. (51). Colonies were grown on potato dextrose agar (PDA) amended with $100 \mathrm{ppm}$ of tetracycline (PDA-tet). Hyphal tips were put on new PDA-tet plates to grow pure cultures. To recover fungi from cankers, the wood surface was treated with $0.5 \%$ sodium hypochlorite for 5 min, after which fragments of necrotic tissue were removed from leading edge of canker margins and placed on petri plates containing PDA-tet. Isolation plates were incubated in the laboratory for 1 week at the ambient laboratory light and temperature conditions.

Identification and morphological study. Identifications of the perithecia of $E$. lata were done using the keys and descriptions of Carter and Rappaz $(4,37)$ and by comparison with type specimens of E. lata (L 0112789-0112795 under Sphaeria lata, Neotype) and E. armeniacae (WARI 4987, Holotype). Internal transcribed spacer (ITS) and $\beta$-tubulin sequences of $E$. lata isolates from California also were compared with GenBank sequences of $E$. lata isolate CBS208.87, which was referred to as E. lata sensu

TABLE 1. Isolates collected for this study and used either in the morphological, phylogenetic, or pathogenicity studies

\begin{tabular}{|c|c|c|c|c|c|c|c|}
\hline \multirow[b]{2}{*}{ Isolate ID $^{v}$} & \multirow[b]{2}{*}{ Fungal species } & \multirow[b]{2}{*}{ Host } & \multirow[b]{2}{*}{ Origin $^{w}$} & \multirow[b]{2}{*}{ Collector $^{x}$} & \multicolumn{3}{|c|}{ GenBank accession no. } \\
\hline & & & & & ITS rDNA ${ }^{y}$ & $\beta$-Tubulin & $\mathrm{RPB}^{\mathrm{z}}$ \\
\hline CAB5A c & Eutypa lata & Vitis vinífera & Napa Co. & F. P. Trouillas & & & \\
\hline DCA700 b & E. lata & $V$. vinifera & Napa Co. & F. P. Trouillas & HM164714 & HM164748 & HM164782 \\
\hline DCA900b & E. lata & $V$. vinifera & Sonoma Co. & F. P. Trouillas & HM164715 & HM164749 & HM164783 \\
\hline DHB $100 \mathrm{~b}$ & E. lata & $V$. vinifera & Sonoma Co. & F. P. Trouillas & & & \\
\hline EAMS100 b & E. lata & $V$. vinifera & Yolo Co. & F. P. Trouillas & HM164730 & HM164764 & HM164798 \\
\hline UCD379St c & E. lata & $V$. vinifera & Stanislauss Co. & J. R. Úrbez-Torres & HM164705 & HM164739 & HM164773 \\
\hline UCD401Mo c & E. lata & $V$. vinifera & Monterey Co. & J. R. Úrbez-Torres & HM164706 & HM164740 & HM164774 \\
\hline UCD715SJ c & E. lata & $V$. vinifera & San Joaquin Co. & J. R. Úrbez-Torres & HM164707 & HM164741 & HM164775 \\
\hline UCD732SJ c & E. lata & $V$. vinifera & San Joaquin Co. & J. R. Úrbez-Torres & HM164708 & HM164742 & HM164776 \\
\hline UCD777St c & E. lata & $V$. vinifera & Stanislauss Co. & J. R. Úrbez-Torres & HM164709 & HM164743 & HM164777 \\
\hline UCD795St c & E. lata & $V$. vinifera & Stanislauss Co. & J. R. Úrbez-Torres & HM164710 & HM164744 & HM164778 \\
\hline DDES200 b & E. lata & Acer macrophyllum & El Dorado Co. & F. P. Trouillas & & & \\
\hline DCA200 b & E. lata & A. macrophyllum & Napa Co. & F. P. Trouillas & HM164718 & HM164752 & HM164786 \\
\hline DAP100 b & E. lata & Prunus armeniaca & Contra Costa Co. & F. P. Trouillas & HM164713 & HM164747 & HM164781 \\
\hline DRO100 b & E. lata & P. armeniaca & Stanislauss Co. & F. P. Trouillas & HM164724 & HM164758 & HM164792 \\
\hline DJAM100 b & E. lata & P. avium & San Joaquin Co. & F. P. Trouillas & HM164719 & HM164753 & HM164787 \\
\hline DMUNK100 b & E. lata & P. avium & San Joaquin Co. & F. P. Trouillas & HM164720 & HM164754 & HM164788 \\
\hline DSC100 b & E. lata & P. avium & Santa Clara Co. & F. P. Trouillas & HM164729 & HM164763 & HM164797 \\
\hline UCCE624 c & E. lata & Malus domestica & Mendocino Co. & F. P. Trouillas & & & \\
\hline DNA100 b & E. lata & Malus sp. & Napa Co. & F. P. Trouillas & HM164721 & HM164755 & HM164789 \\
\hline DPEAR100 b & E. lata & Pyrus communis & El Dorado Co. & F. P. Trouillas & HM164722 & HM164756 & HM164790 \\
\hline DPEAR200 b & E. lata & P. communis & El Dorado Co. & F. P. Trouillas & HM164723 & HM164757 & HM164791 \\
\hline DRUSS100 b & E. lata & Prunus dulcis & Yolo Co. & F. P. Trouillas & HM164725 & HM164759 & HM164793 \\
\hline DCHR100 b & E. lata & Salix cf lasiolepis & Napa Co. & F. P. Trouillas & HM164716 & HM164750 & HM164784 \\
\hline DCHR200 b & E. lata & S. cf lasiolepis & Napa Co. & F. P. Trouillas & HM164717 & HM164751 & HM164785 \\
\hline DSA200 b & E. lata & Salix sp. & San Joaquin Co. & F. P. Trouillas & HM164726 & HM164760 & HM164794 \\
\hline DSA300 b & E. lata & Salix sp. & Contra Costa Co. & F. P. Trouillas & & & \\
\hline DSA400 b & E. lata & Salix sp. & Santa Clara Co. & F. P. Trouillas & HM164727 & HM164761 & HM164795 \\
\hline DSA500 b & E. lata & Salix sp. & Napa Co. & F. P. Trouillas & HM164728 & HM164762 & HM164796 \\
\hline WILLOWC c & E. lata & Salix sp. & Napa Co. & F. P. Trouillas & HM164731 & HM164765 & HM164799 \\
\hline DCHES200 b & E. lata & Aesculus californica & Sonoma Co. & F. P. Trouillas & HM164732 & HM164766 & HM164800 \\
\hline OLEA2 b & E. lata & Nerium oleander & Yolo Co. & F. P. Trouillas & & & \\
\hline OLEA3 b & E. lata & N. oleander & Yolo Co. & F. P. Trouillas & HM164733 & HM164767 & HM164801 \\
\hline $3802 \mathrm{~b}$ & E. lata & Frangula alnus & Roches, Switzerland & F. Rappaz & HM164711 & HM164745 & HM164779 \\
\hline $1908021 \mathrm{~b}$ & E. lata & Hedera helix & Roches, Switzerland & F. Rappaz & HM164712 & HM164746 & HM164780 \\
\hline CBS217.87 a & E. lata var. aceri & Acer campestre & France & F. Rappaz & HM164734 & HM164768 & HM164802 \\
\hline CBS290.87 a & E. lata var. aceri & A. pseudoplatanus & Switzerland & F. Rappaz & HM164736 & HM164770 & HM164804 \\
\hline CBS291.87 a & E. laevata & Salix sp. & Switzerland & F. Rappaz & HM164737 & HM164771 & HM164805 \\
\hline DSA600 b & E. cf laevata & Salix lasiolepis & San Joaquín Co. & F. P. Trouillas & HM164738 & HM164772 & HM164806 \\
\hline DRSN100 b & E. leptoplaca & $V$. vinifera & Sonoma Co. & F. P. Trouillas & AY684236 & AY684211 & HM164807 \\
\hline CBS244.87 a & E. petrakii var. petrakii & P. spinosa & Switzerland & F. Rappaz & HM164734 & HM164769 & HM164803 \\
\hline UCD730SJ c & Cryptosphaeria pullmanensis & V. vinifera & San Joaquín Co. & J. R. Úrbez-Torres & GQ293929 & GQ294013 & HM164808 \\
\hline
\end{tabular}

$\mathrm{v}$ Isolate received as pure culture (a), obtained from perithecia (b), or isolated from canker (c).

${ }^{\mathrm{w}}$ Co. $=$ county in California, United States.

${ }^{x}$ Collector or isolator.

y Internal transcribed spacer (ITS) ribosomal (r)DNA.

${ }^{z}$ RPB2 = DNA-dependant RNA polymerase II. 
stricto by Rolshausen et al. (40). Perithecia and stromata characteristics were examined in the laboratory using a stereoscopic microscope (Leica MZ95). Perithecial contents were mounted in water and examined by light microscopy (Leica DM LB). Ascospores and conidia of the various isolates collected were measured in water with a bright-field compound microscope at $\times 1,000$ magnification. Measurements were taken on 90 ascospores/isolate. Thirty conidia per isolate were measured as conidial masses became visible from colonies maintained under fluorescent lighting (Underwriters Laboratories Inc., Georgia) (12 h/day) at $24^{\circ} \mathrm{C}$. Conidia measurements reflected the straight-line distance between the endpoints of the spore (chord length). Means of ascospore and conidium sizes were compared statistically using analysis of variance (ANOVA) and Tukey's highly significant difference test in SAS (version 9.1; SAS Institute, Cary, NC).

DNA extraction, sequence alignment, and phylogenetic analyses. Phylogenetic analyses were carried out to confirm results of morphological identification and further analyze the intraspecific variation of E. lata isolates from California. Phylogenetic analyses were based on the sequence comparison of the ITS region of the ribosomal (r)DNA, portions of the $\beta$-tubulin and DNA-dependant RNA polymerase II (RPB2) genes. Multigene phylogeny of the combined datasets of the ITS, $\beta$-tubulin, and $R P B 2$ genes were also carried out.

DNA was extracted from fresh mycelium of pure cultures using a commercial DNA extraction kit (Bio-Rad Laboratories, Hercules, CA). The 5.8S nuclear rDNA region and ITS1 and ITS2 were amplified by polymerase chain reaction (PCR) using primers ITS1 and ITS4 (54). The $\beta$-tubulin gene was amplified using primers T1 (27) and Bt2b (11). DNA-dependant RNA polymerase II gene was amplified using primers $R P B 2-7 \mathrm{~F}$ and $R P B 2-$ $11 \mathrm{aR}$ (17). Samples were then processed through 35 cycles at $94^{\circ} \mathrm{C}$ for $1 \mathrm{~min}, 58^{\circ} \mathrm{C}$ for $1 \mathrm{~min}$, and $72^{\circ} \mathrm{C}$ for $1 \mathrm{~min}$ and $30 \mathrm{~s}$ for amplification in a programmable thermal controller machine. PCR products were purified using QIAquick PCR Purification Kit (Qiagen Inc., Valencia, CA). Both strands of the three DNA regions were sequenced using the ABI Prism 377 DNA Sequencer (Perkin-Elmer, Norwalk, $\mathrm{CN}$ ) at the Division of Biological Sciences sequencing facility at the University of California, Davis. Sequencing results were edited and assembled using Sequencher version 3.1.1. Sequences were aligned using ClustalW multiple alignment program (49) and sequence alignments were improved manually. Phylogenetic analyses were performed with PAUP version $4.0 b 10$ (47) using maximum parsimony (MP) with a heuristic search and 1,000 random addition sequence replicates and tree bisection-reconnection (TBR) as the branch swapping algorithm. Branches of zero length were collapsed and all multiple, equally parsimonious trees were saved. Measures including tree length, consistency index (CI), retention index (RI), and rescaled consistency index (RC) were calculated. All characters were unordered and equally weighted. Alignment gaps were treated as missing data. Bootstrap support (BS) was evaluated using 1,000 replicates to test branch strengths. Branches with bootstrap value $<50 \%$ are not represented. Phylogenetic analyses neighbor-joining (NJ) analyses were also performed to test results obtained from the MP analyses. Trees were rooted with Cryptosphaeria pullmanensis and E. leptoplaca as outgroups.

Pathogenicity tests. Two pathogenicity tests were conducted on $V$. vinifera grapevines using green shoots. A field experiment was conducted on mature Sauvignon Blanc grapevines planted at the Viticulture department experimental station of the University of California, Davis. Shoots were inoculated in June 2007 using 19 isolates of $E$. lata obtained from various host plants (Table 1). Inoculations were made at internodes 4 to 6 using a 4-mm cork borer and placing an agar plug with fresh mycelium obtained from the margin of 10-day-old colonies. One cane on each of six grapevine plants per fungal treatment was inoculated in a completely randomized design. Control shoots were inoculated in the same way using sterile agar plugs. Inoculations were then covered with petroleum jelly and wrapped with Parafilm (Pechiney, Chicago). Shoots were collected after 8 months for measurement of the total length of vascular discoloration extending upward and downward from the point of inoculation. Canes were surface disinfected using $0.5 \%$ sodium hypochlorite for $5 \mathrm{~min}$ and air dried. Fragments of necrotic tissue developing outside the area of inoculation were cultured on PDA-tet from the leading edge of canker, and E. lata isolates obtained from reisolation were identified based on colony shape, color, and growth rate.

A second experiment was conducted in green shoots of 3-yearold potted Chardonnay grapevine plants maintained in a lath house at the field station of the Plant Pathology department of the University of California, Davis. Inoculations were done as described above using 18 of the 19 isolates of E. lata used in the first experiment. One shoot on each of five plants per isolate and control were inoculated in a completely randomized design. Observations of the length of vascular discolorations and reisolations were done 10 months following inoculations.

Statistical analyses were performed using ANOVA in SAS (version 9.1). Log transformations were performed to reduce heteroscedasticity and stabilize variance. Fisher's least significance difference (LSD) test was used to assess significant differences in the extent of vascular discoloration between the different treatment group means.

\section{RESULTS}

Surveys. The host range and geographic distribution of the perithecia of E. lata in California are summarized in Figure 1. Agricultural crop hosts in this study on which perithecia of E. lata were identified included crabapple (Malus sp.) in Napa County; pear (Pyrus communis) in Mendocino, El Dorado, and Sacramento Counties; sweet cherry (Prunus avium) in San Joaquin and San Benito Counties; apricot ( $P$. armeniacae) in San Joaquin, Contra Costa, Stanislaus, and San Benito Counties; and grapevine (V. vinifera) in San Joaquin, San Benito, Napa, Sonoma, Yolo, and El Dorado Counties. Stromata of E. lata on almond (P. dulcis) were rare and only one tree with a poorly developed stroma was found in an orchard in Yolo County, despite extensive surveys of almond orchards in Central and Northern California. Perithecia in vineyards and apricot and cherry orchards were found mostly in $\approx 20$-year and older plantings.

In addition, the sexual stage of E. lata was found on trees in riparian areas and natural forests. Perithecia were particularly common on dead branches of willows (Salix lasiolepis) in the counties of Napa, San Benito, Stanislaus, Sacramento, Yolo, Merced, Solano, and San Joaquin. Perithecia also were collected commonly from the dead wood of big leaf maple (Acer macrophyllum) in the Napa and El Dorado Counties and on California buckeye (Aesculus californica) in some mixed evergreen forest of Napa and Sonoma Counties. E. lata perithecia also were found on oleander (Nerium oleander) in Yolo County.

Morphological study. Mean length of ascospores for all putative isolates of $E$. lata ranged between $8.3 \pm 0.6 \mu \mathrm{m}$ (isolate DCHES200) and $9.7 \pm 1.1 \mu \mathrm{m}$ (DCHR100) and were significantly different among isolates $(P<0.0001)$ (Table 2$)$. ANOVA revealed significant differences in conidia size among isolates of $E$. lata $(P<0.0001)$. Conidia sizes varied between $23.6 \pm 2.4 \mu \mathrm{m}$ (DCHR200) and 35.0 $\pm 4.0 \mu \mathrm{m}$ (isolate DAP100). Mean length of ascospores and conidia of isolate DSA600 (7.6 \pm 0.9 and $54.6 \pm$ $7.2 \mu \mathrm{m}$, respectively) significantly differed from all other isolates (Table 2), which separated from E. lata also in phylogenetic analyses.

Phylogeny. PCR amplifications using primers ITS1 and ITS4 gave products of $\approx 0.56 \mathrm{~kb}$. The $5.8 \mathrm{~S}$ rDNA region was conserved among all the strains. Parsimony analysis of the molecular data set generated nine MP trees. One of the nine MP trees derived 
from the analysis of the rDNA-ITS region is shown in Figure 2A. A complete alignment was achieved for $566 \mathrm{bp}$, with 480 constant characters, 46 parsimony-informative characters, and 40 parsimony-uninformative characters. The length of the tree was 111 steps, with $\mathrm{CI}=0.8559, \mathrm{RI}=0.8416$, and $\mathrm{RC}=0.7203$. Although the relationship of isolates within the E. lata clade varied between the nine MP trees, all MP trees generated identical lineages.

The $\beta$-tubulin dataset consisted of 605 characters after alignment; 392 were constant, 143 were parsimony-uninformative, and 70 were parsimony-informative. The analysis retained one MP tree of 283 steps after the heuristic search $(\mathrm{CI}=0.9152, \mathrm{RI}=$ 0.8983, and $\mathrm{RC}=0.8221$ ) (Fig. 2B).
The parsimony heuristic analysis of the $R P B 2$ gene yielded one MP tree with length of 195 steps $(\mathrm{CI}=0.9077, \mathrm{RI}=0.8741$, and $\mathrm{RC}=0.7934$ ) (Fig. 2C). The aligned RPB2 dataset contained 824 characters, of which 666 were constant, 89 were parsimony-uninformative, and 69 were parsimony-informative.

The combined data set of the ITS-rDNA, $\beta$-tubulin, and RPB2 contained 1,995 characters, with 1,538 constant characters, 272 parsimony-uninformative characters, and 185 parsimony-informative characters. The heuristic search resulted in 6,879 equally MP trees 611 steps long, with $\mathrm{CI}=0.7377, \mathrm{RI}=0.8333$, and $\mathrm{RC}=$ 0.7242. All 6,879 MP trees shared similar lineage topology (Fig. 2D).

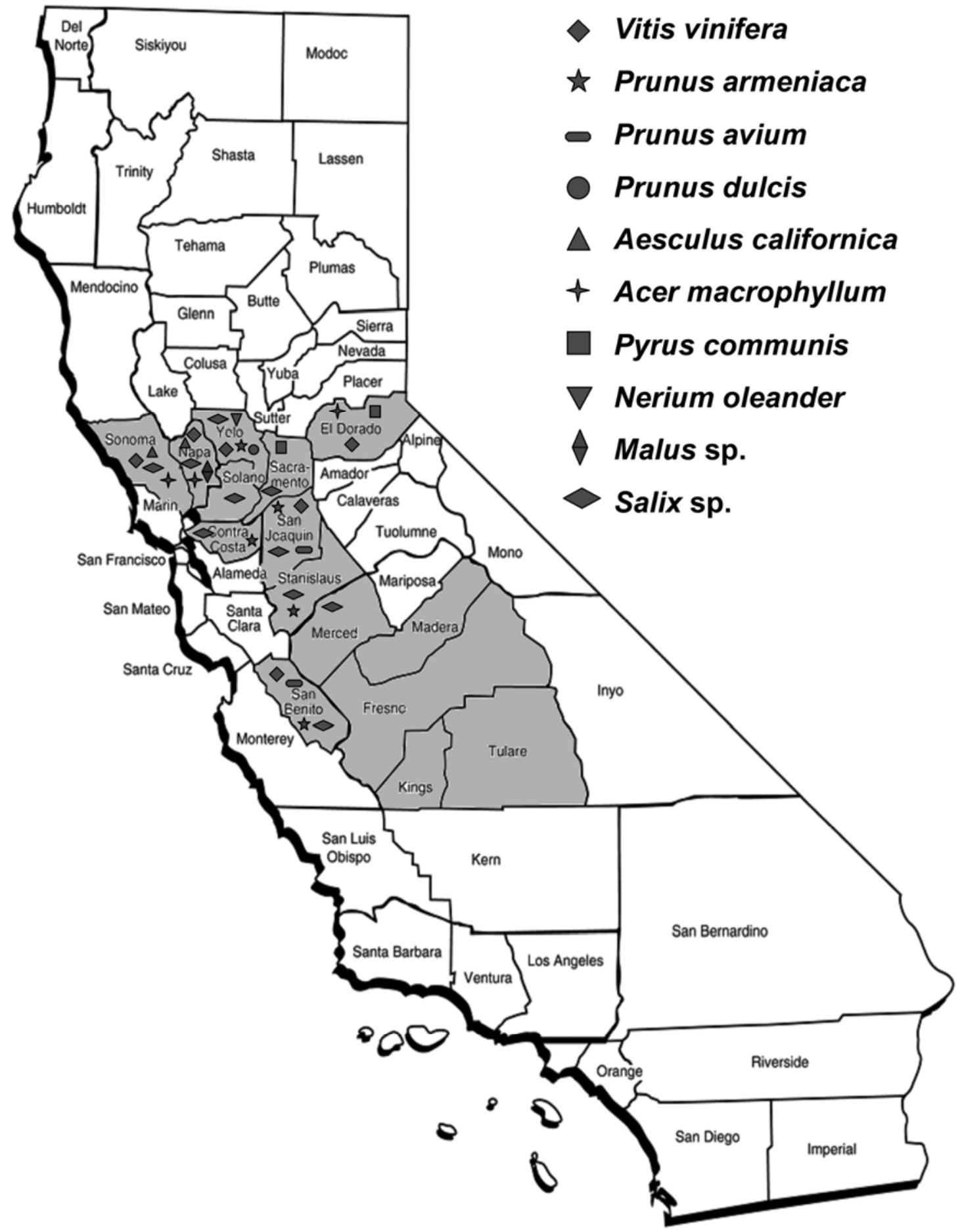

Fig. 1. Host range and geographical distribution of the perithecial stage of Eutypa lata in the main grape-growing regions of California. Areas with gray background correspond to areas that were surveyed. 
$\mathrm{NJ}$ analyses generated tree topologies identical to those obtained using MP analyses for all data sets. Therefore, only results of MP analyses were used to illustrate tree topologies.

All sequence analyses using the three nuclear regions were concordant and distinguished four closely related and previously recognized morphospecies, including E. lata, E. lata var. aceri, E. laevata, and E. petrakii var. petrakii. Isolates of E. lata from California were similar to E. lata reference isolates CBS208.87 (40) as well as E. lata isolates 3802 and 1908021 (ITS, $\beta$-tubulin, and $R P B 2$ sequence comparison) obtained from Rappaz, thus confirming morphological identifications. All analyses also separated isolate DSA600 from the main clade of E. lata isolates and suggested that it is related to E. laevata isolate CBS 291.87. All other isolates from California formed a monophyletic clade recognized as E. lata and including collections made from fruit trees and wine grapes, as well as natural and ornamental host plants. Several isolates of E. lata from California were unevenly separated into subclades; however, the low bootstrap values associated with these clades suggested that they do not constitute distinct species but, rather, illustrate genetic variation for E. lata. On the other hand, a major clade with strong bootstrap support, including all isolates collected (except for isolate DSA600), was identified in all analyses. These major clades are regarded as $E$. lata sensu stricto in the present study.

Pathogenicity tests. Green shoot inoculations of Sauvignon Blanc grapevines with E. lata isolates collected in the survey showed that most isolates were capable of causing disease. After 8 months, the extent of vascular discoloration induced by $E$. lata isolates varied almost continuously from 10.8 to $32.2 \mathrm{~mm}$ (DRUSS100) (Fig. 3A). ANOVA revealed highly significant differences (at $\alpha=0.05)$ among the isolates $(P<0.0001)$. Fisher's LSD test showed significant differences between some isolates, indicating a gradient of virulence among the various isolates (Fig. $3 \mathrm{~A})$. Percentage of inoculations from which the pathogen was recovered varied from $0 \%$ for plants inoculated with isolates DMUNK100 and DSA300 from cherry and willow trees, respectively, to low to moderate for plants inoculated with isolates UCD401 (V. vinifera), DRUSS100 (P. dulcis), and DCA900 (Acer macrophyllum), which were recovered at 16.7, 33.4, and $57.4 \%$, respectively. Percentage of recovery for all other isolates was 66.7 to $100 \%$.

TABLE 2. Mean length of ascospore and conidium of putative Eutypa lata isolates collected for this study ${ }^{\mathrm{z}}$

\begin{tabular}{lcc}
\hline Isolate ID & $\begin{array}{c}\text { Mean length of } \\
\text { ascospores }(\mu \mathrm{m}) \pm \mathrm{SD}\end{array}$ & $\begin{array}{c}\text { Mean length (chord length) of } \\
\text { conidia }(\mu \mathrm{m}) \pm \mathrm{SD}\end{array}$ \\
\hline DCHR100 & $9.7 \pm 1.1 \mathrm{a}$ & $29.3 \pm 2.8 \mathrm{defg}$ \\
DMUNK100 & $9.5 \pm 1.1 \mathrm{ab}$ & $\begin{array}{c}\text { ab } \\
\text { nd }\end{array}$ \\
EAMS100 & $9.4 \pm 1.1 \mathrm{abc}$ & $31.3 \pm 3.4 \mathrm{~cd}$ \\
DSC100 & $9.4 \pm 1.1 \mathrm{abc}$ & $23.6 \pm 2.4 \mathrm{~h}$ \\
DCHR200 & $9.4 \pm 1.2 \mathrm{abcd}$ & $26.8 \pm 3.4 \mathrm{gh}$ \\
DJAM100 & $9.3 \pm 1.2 \mathrm{abcde}$ & $27.5 \pm 4.2 \mathrm{fg}$ \\
DSA200 & $9.3 \pm 1.1 \mathrm{abcde}$ & $30.6 \pm 2.5 \mathrm{def}$ \\
DPEAR200 & $9.2 \pm 0.1 \mathrm{abcde}$ & $28.0 \pm 4.7 \mathrm{efg}$ \\
DNA100 & $9.2 \pm 1.0 \mathrm{abcde}$ & nd \\
DHB100 & $9.1 \pm 1.0 \mathrm{bcdef}$ & $29.3 \pm 2.3 \mathrm{defg}$ \\
DCA90 & $9.1 \pm 1.0 \mathrm{bcdef}$ & $35.0 \pm 4.0 \mathrm{~b}$ \\
DAP100 & $9.1 \pm 1.1 \mathrm{bcdefg}$ & $30.7 \pm 3.9 \mathrm{cde}$ \\
DCA700 & $9.0 \pm 0.8 \mathrm{bcdefg}$ & nd \\
DCA200 & $8.9 \pm 1.2 \mathrm{cdefg}$ & $34.6 \pm 2.4 \mathrm{~b}$ \\
DRO100 & $8.9 \pm 1.0 \mathrm{cdefgh}$ & nd \\
DSA500 & $8.9 \pm 0.8 \mathrm{defgh}$ & $27.8 \pm 1.8 \mathrm{efg}$ \\
DSA300 & $8.8 \pm 1.1 \mathrm{efgh}$ & nd \\
DSA400 & $8.6 \pm 0.1 \mathrm{fgh}$ & $26.2 \pm 2.5 \mathrm{gh}$ \\
OLEA3 & $8.5 \pm 0.7 \mathrm{gh}$ & $54.6 \pm 7.2 \mathrm{a}$ \\
DCHES200 & $8.3 \pm 0.6 \mathrm{~h}$ & \\
DSA600 & $7.6 \pm 0.9 \mathrm{i}$ & \\
\hline
\end{tabular}

${ }^{\mathrm{z}}$ Means followed by different letters differ significantly $(\alpha=0.05)$ according to Tukey's highly significant difference test. $\mathrm{SD}=$ standard deviation and nd $=$ not determined.
Green shoot inoculation of Chardonnay grapevines with the wide host range collection of E. lata showed that all isolates tested were capable of infecting grapevine shoots. After 10 months, the extent of vascular discoloration varied from $7.6 \mathrm{~mm}$ (isolate DSA200) to $16.8 \mathrm{~mm}$ (DSC100). Mean of vascular discoloration observed in the control was $5.6 \mathrm{~mm}$ (Fig. 3B). ANOVA showed significant differences (at $\alpha=0.05)$ among the treatments $(P=$ 0.0216). Fisher's LSD test revealed significant differences of virulence among the various isolates tested (Fig. 3B). Percentage of recovery was only $20 \%$ for isolate DPEAR100; all other percentages of recovery were high across the experiment and varied from 60 to $100 \%$ for the isolates tested.

\section{DISCUSSION}

In California, damage due to Eutypa dieback has a severe economic impact on the wine industry (42), yet no eradicative control methods are available, except for severe pruning. Most control methods rely on preventing infection using pruningwound protectants, as well as appropriate cultural practices, sanitation methods, and remedial surgery $(39,43-45,53)$. Identifying the inoculum sources for the disease constitutes critical knowledge of disease epidemiology and may ultimately help to reduce risks of infection if these sources can be eliminated.

In this study, surveys revealed that perithecia of E. lata occur in the main wine regions of the North and Central Coasts and in the Sacramento and Northern San Joaquin Valleys in California. Perithecia of E. lata were found to be prevalent in the counties of Napa, Sonoma, Yolo, Sacramento, Contra Costa, San Benito, El Dorado, Mendocino, San Joaquin, and Stanislaus. In fruit crops, stromata of E. lata were common in many of the older cherry and apricot orchards and vineyards that were surveyed. Several trees in a cherry orchard in San Joaquin County previously reported to have perithecia (26) were still bearing viable ascomata. Trees and vines with stromata generally were associated with large pruning wounds on the scaffold or main trunk. Stromata spread widely along the trunk surface and often shared alternate zones of living and dead perithecia. New hosts for the sexual stage of E. lata in California on woody crops included crabapple (Malus sp., not Malus domestica) and pear (Pyrus communis). Preliminary surveys for pathogens associated with dieback in commercial apple trees $(M$. domestica) in California have revealed an abundance of E. lata in cankers collected from diseased trees in Mendocino County (10). Other studies in the United States have shown the association of $E$. lata with a canker disease of $M$. domestica (12).

In the present study, we report the occurrence of perithecia on common native Californian trees including A. macrophyllum, Aesculus californica, and S. lasiolepis and on ornamentals such as $N$. oleander. Perithecia of E. lata were found to be particularly well established on dead branches of willow species occurring along natural creeks and irrigation waterways. Stromata were common and usually well developed on the dead wood of willow, which suggested that this host plant might represent an important reservoir of inoculum. This work introduces the role of ornamental plants and native vegetation as potential inoculum sources for Eutypa dieback in California and illustrates the increased importance of grapevine as an overwintering host. In many wine regions of California, vineyards have been planted near riparian areas, forests, and managed landscapes. Pathogenicity tests have shown that E. lata isolates collected from native, ornamental, and agricultural hosts could cause Eutypa dieback of grapevine. The role of native vegetation in the epidemiology of Eutypa dieback remains to be established but removal of the dead wood of potential hosts of E. lata in proximity to vineyards may be advisable. Removal and burning of infected wood, which can usually be identified by the distinctive black stroma of E. lata, should reduce the number of spores released in winter. 
No perithecia were detected from surveys conducted in Tulare, Fresno, Madera, Kings, and Kern Counties. Yearly average rainfall is $266 \mathrm{~mm}$ in Tulare County, $145 \mathrm{~mm}$ in Kern County, and $304 \mathrm{~mm}$ in Fresno and Madera Counties. These findings are consistent with previous reports suggesting an influence of rainfall on the distribution of $E$. lata perithecia (4). Also, UrbezTorres et al. (52) showed a low or zero incidence of E. lata in grapevine wood cankers collected from grapevines grown in these

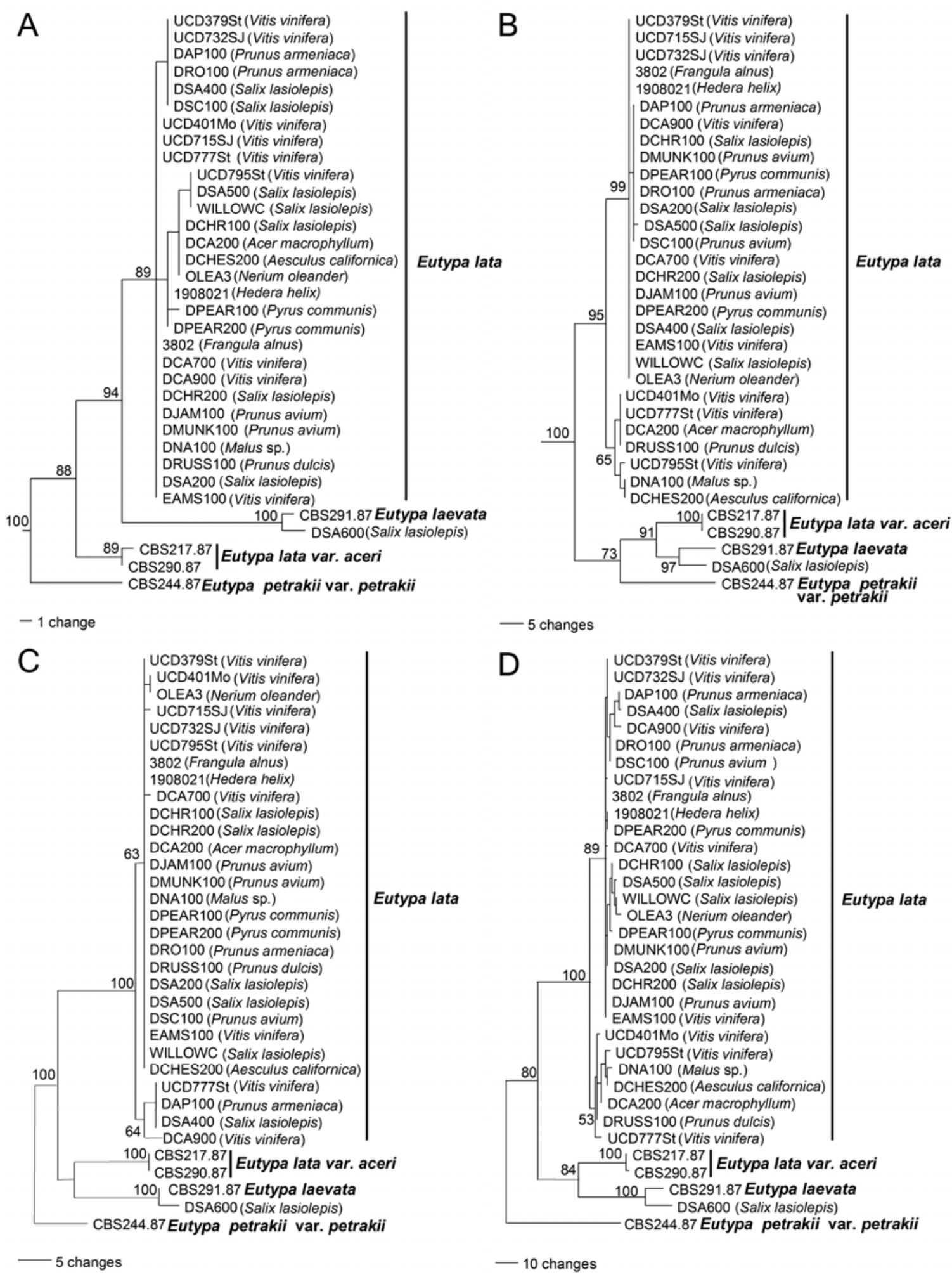

Fig. 2. A, One of the nine most-parsimonious trees obtained from the internal transcribed spacer (ITS) sequence data; tree length (TL) $=111$ steps, consistency index $(\mathrm{CI})=0.8559$, retention index $(\mathrm{RI})=0.8416$, and rescaled consistency index $(\mathrm{RC})=0.7203$. Bootstrap support values from 1,000 replicates $>50 \%$ are reported at the nodes. B, Most-parsimonious trees obtained from the $\beta$-tubulin sequence data; $\mathrm{TL}=283$ steps, $\mathrm{CI}=0.9152, \mathrm{RI}=0.8983$, and $\mathrm{RC}=0.8221$. Bootstrap support values from 1,000 replicates $>50 \%$ are reported at the nodes. C, Most-parsimonious trees obtained from the RPB2 sequence data; TL $=195$ steps, $\mathrm{CI}=0.9077, \mathrm{RI}=0.8741$, and $\mathrm{RC}=0.7934$. Bootstrap support values from 1,000 replicates $>50 \%$ are reported at the nodes. $\mathbf{D}$, One of the 6,879 mostparsimonious trees obtained from the combined ITS, $\beta$-tubulin, and $R P B 2$ sequence data; $\mathrm{TL}=611$ steps, $\mathrm{CI}=0.8691, \mathrm{RI}=0.8333$, and $\mathrm{RC}=0.7242$. Bootstrap support values from 1,000 replicates $>50 \%$ are reported at the nodes. 
southern regions and further showed the prevalence of Botryosphaeriaceae fungi as the cause of grapevine cankers in the southern San Joaquin Valley. Moreover, the distribution of E. lata perithecia in California appears to coincide with the distribution of the disease. The identification of many new hosts on which $E$. lata produces perithecia calls into question the importance of long-distance dispersal of ascospores in causing infections on grapevines in the San Joaquin Valley $(28,36)$.
The occurrence of the sexual stage of E. lata on cultivated grapevine and fruit trees as well as on native plant species in forests and riparian areas raises questions about the origin of the pathogen. Carter and Peros have discussed the possibilities that $E$. lata originally acquired its pathogenicity in grapevine in Asia Minor and, subsequently, expanded its range of susceptible hosts $(4,31)$. Another possibility suggested by the same authors $(4,31)$ is that E. lata was present as a weak pathogen on different host

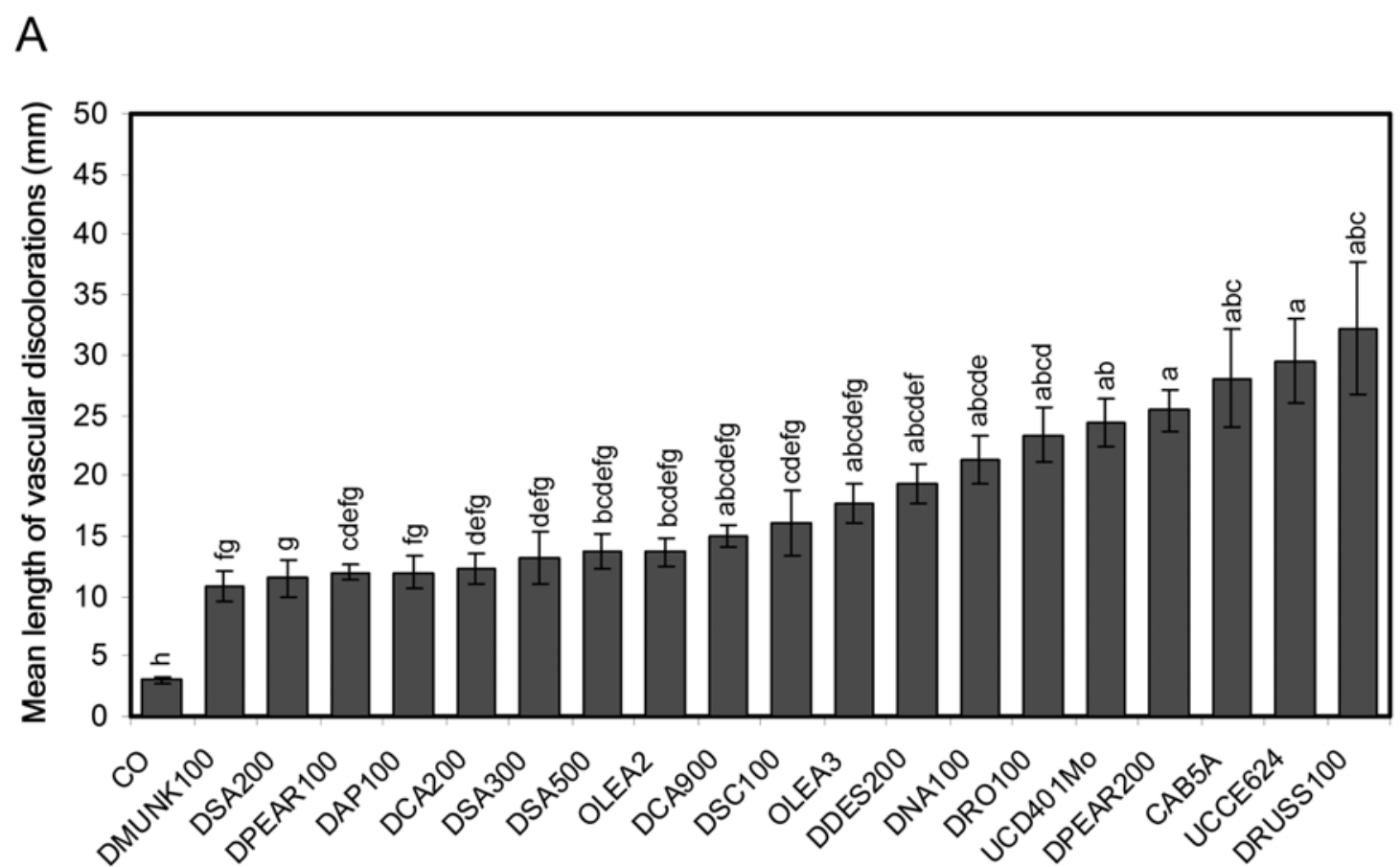

Fungal isolates

\section{$\mathrm{B}$}

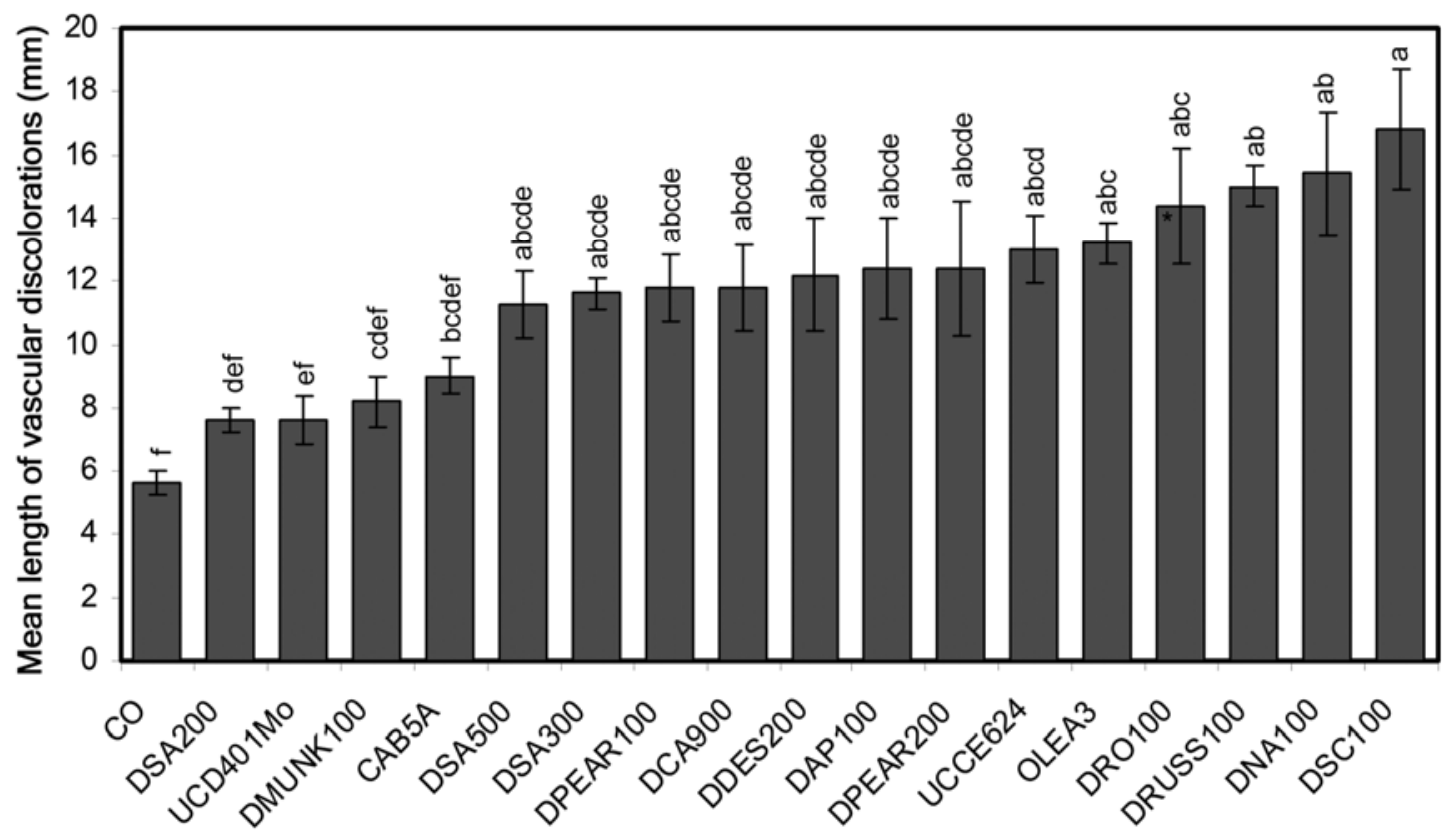

Fungal isolates

Fig. 3. A, Mean length of vascular discolorations 8 months after inoculation of various isolates of Eutypa lata in Sauvignon Blanc grapevine green shoots under field conditions using mycelium plugs. Isolates with mean lengths of vascular discoloration followed by different letters were significantly different from each other according to Fisher's least significant difference (LSD) $(\alpha=0.005)$. B, Mean length of vascular discoloration 10 months after inoculation of various isolates of E. lata in Chardonnay grapevine green shoots inoculated using mycelium plugs and maintained in a lath house. Isolates with mean lengths of vascular discoloration followed by different letters were significantly different from each other according to Fisher's LSD $(\alpha=0.005)$. 
plants around the world and only recently has developed the ability to kill agricultural crops such as apricot and grape. Recently, a study of members of Diatrypaceae associated with grapevine canker diseases has suggested that these fungi may constitute opportunistic pathogens occurring naturally on the indigenous flora but capable of infecting newly introduced agricultural host plants (51). Surveys in Central Europe have shown that E. lata apparently occurs on many native plant species in this region, seemingly coexisting in a state of equilibrium without causing disease to the hosts, which suggests that host and fungus have long been associated (4). The coevolution event in a host-pathogen combination has been known to favor a high level of resistance of a particular host and, reciprocally, a low degree of virulence of a pathogen (46). The evolutionary history of E. lata and trend (direction) of host-jumping events between indigenous and domesticated flora should be investigated next to differentiate the founder populations of the pathogen and elucidate the origin (emergence) of diseases caused by the fungus $E$. lata in California.

The dominant operational species concept in E. lata has been the morphological species concept (48), and no biological species concept has yet been established for $E$. lata despite previous attempts to obtain sexual fruiting bodies in vitro from sexual reproduction of compatible isolates (P. E. Rolshausen, personal communication). Moreover, identification of the teleomorph of $E$. lata has been based generally on the examination of ascospore shape and size, perithecial organization within stroma (37), and shape of perithecial ostioles $(37,50)$. In this study, we detected morphological plasticity and provided an expected range of ascospore and conidium size. Moreover, disease diagnosis for Eutypa dieback has been done mostly by isolating the pathogen from cankered tissues and observing typical white colonies and filiform conidia on PDA medium. However, because of the difficulty in separating E. lata from closely related Eutypa spp. using morphology alone (13), and the occurrence on grapevine of related species $(41,50,51)$, molecular- and metabolite-based techniques have been recently developed to accurately identify $E$. lata $(14,16,19,41)$.

Identification of E. lata from the various hosts was confirmed using multigene phylogenies of rDNA ITS, $\beta$-tubulin, and $R P B 2$ genes. The analyses also revealed sequence differences among isolates, indicating some intraspecific genetic diversity for $E$. lata populations from California. However, the degree of phylogenetic diversity and the intraspecific groups were not consistent across the various DNA phylogenies. Moreover, subgroups did not correlate with the sampling site or source of isolation. One probable explanation is that random mating and gene flow through dispersal of ascospore are sufficient to preclude differentiation of regional populations $(30,32)$. Moreover, the proximity of native hosts for E. lata to cultivated hosts may play a major role in defining the overall population structure of the pathogen and unrestricted gene flow (31).

Under the conditions of our tests, all isolates of E. lata from California were infectious to grapevines but differences in virulence were significant. These results are in agreement with previous reports of great diversity in aggressiveness among strains of E. lata from the same country, within a single vineyard, and even from the same stroma (29-33). Similar indications of diversity are apparent from reports of differential production of secondary metabolites across strains of E. lata $(18,24,38,40)$. Isolates DMUNK100 and DSA300 from cherry and willow trees, respectively, could not be reisolated from the previously inoculated Sauvignon Blanc shoots. This indicates that these isolates were probably not pathogenic to the Sauvignon Blanc cultivar under the condition of our experiment.

Overall, differences in ascospore and conidium length as well as differences in virulence on grapevine shoots did not correlate with differences in DNA sequences or phylogenetic groups. Our results illustrate the intraspecific phenotypic and genetic variation within the species $E$. lata inferred by examination of numerous isolates from California. Morphology and, most particularly, ascospore and conidium sizes generally provide important taxonomy features useful for diagnostic. Here, we characterized the intraspecific morphological variation of E. lata using multiple strain measurements of ascospores and conidia. Because of the many strains examined for this study, our results provide confident size ranges for these morphological characters. The morphological and phylogenetic analyses excluded the willow isolate DSA600 (initially considered as E. lata based on perithecia and colony morphologies) from the main clade of $E$. lata isolates. These analyses also suggested that it relates to E. laevata.

Previous studies have analyzed the population structure of $E$. lata at various geographical scales, varying from a single vineyard population to continental populations. The studies have shown high levels of genetic diversity among populations of $E$. lata in Europe, Australia, and North America using randomly amplified polymorphic DNA, amplified fragment length polymorphism, isozyme, and vegetative compatibility data (6,15,30-35).

The wide geographical distribution and host range of the pathogen $E$. lata have raised questions about the true boundaries of this species. In this study, we have concluded, on the basis of phylogenetic analyses of the ITS region of the rDNA and portions of the $\beta$-tubulin and DNA-dependant RNA polymerase II genes, that the wide host range and phenotypic variations observed among isolates corresponded to the intraspecies variability of California populations of E. lata sensu stricto. Therefore, the occurrence of putative cryptic species of Eutypa among isolates in our collection of E. lata from California is doubtful but future research should further investigate the population structure and genetic diversity of $E$. lata for possible subdivisions, as well as levels of gene flow occurring between agroecosystems and native environment populations of the pathogen.

\section{ACKNOWLEDGMENTS}

We thank the American Vineyard Foundation and the Viticulture Consortium West for financial support.

\section{LITERATURE CITED}

1. Acero, F. J., Gonzalez, V., Sanchez-Ballesteros, J., Rubio, V., Checa, J., Bills, G. F., Salazar, O., Platas, G., and Pelaez, F. 2004. Molecular phylogenetic studies of the Diatrypaceae based on rDNA-ITS sequences. Mycologia 96:249-259.

2. Bolay, A., and Moller, W. J. 1977. Eutypa armeniacae Hansf. \& Carter, agent d'un grave dépérissement de vignes en production. Rev. Suisse Vitic. Arboric. Hortic. 9:241-251.

3. Carter, M. V. 1957. Eutypa armeniacae Hansf., and Carter, sp. nov., an airborne vascular pathogen of Prunus armeniaca L. in southern Australia. Aust. J. Bot. 5:21-35.

4. Carter, M. V. 1991. The status of Eutypa lata as a pathogen. Phytopathological Paper No. 32. CAB International, Wallingford, England.

5. Carter, M. V., Bolay, A., and Rappaz, F.1983. An annotated host list and bibliography of Eutypa armeniacae. Rev. Plant Pathol. 62:251-258.

6. DeScenzo, R. A., Engel, S. R., Gomez, G., Jackson, E. L., Munkvold, G. P., Weller, J., and Irelan, N. A. 1999. Genetic analysis of Eutypa strains from California supports the presence of two pathogenic species. Phytopathology 89:884-893.

7. English, H., and Davis, J. R. 1965. Apricot dieback fungus found on western chokecherry. Plant Dis. Rep. 49:178.

8. English, H., and Davis, J. R. 1978. Eutypa armeniacae in apricot: pathogenesis and introduction of xylem soft rot. Hilgardia 46:193-204.

9. English, H., Davis, J. R., Ogawa, J. M., and Schick, F. J. 1983. Variation in Eutypa armeniacae and discovery of its ascigerous stage in California's central valley. (Abstr.) Phytopathology 73:958.

10. Gallegos, L. L, Rooney-Latham, S., Eskalen, A., Elkins, R., and Gubler, W. D. 2007. Fungal diseases of grapevine common on apples? (Abstr.) Phytopathology 97:S38.

11. Glass, N. L., and Donaldson, G. C. 1995. Development of primer set designed for use with the PCR to amplify conserved genes from filamentous ascomycetes. Appl. Environ. Microbiol. 61:1323-1330. 
12. Glawe, D. A., Dilley, M. A., and Moller, W. J. 1983. Isolation and identification of Eutypa armeniacae from Malus domestica in Washington state. Mycotaxon 18:315-318.

13. Glawe, D. A., and Rogers, J. D. 1984. Diatrypaceae in the Pacific Northwest. Mycotaxon 20:401-460.

14. Lardner, R., Scott, E. S., and Stummer, B. E. 2007. Genetic variation in Australian isolates of the grapevine pathogen Eutypa lata. Australas. Plant Pathol. 36:149-156.

15. Lardner, R., Stummer, B. E., Sosnowski, M. R., and Scott, E. S. 2005. Molecular identification and detection of Eutypa lata in grapevine. Mycol. Res. 109:799-808.

16. Lecomte, P., Péros, J. P., Blancard, D., Bastien, N., and Délye, C. 2000. PCR assays that identify the grapevine dieback fungus Eutypa lata. Appl. Environ. Microbiol. 66:4475-4480.

17. Liu, Y. J., Whelen, S., and Hall, B. D. 1999. Phylogenetic relationships among ascomycetes: evidence from an RNA polymerase II subunit. Mol. Biol. Evol. 16:1799-1808.

18. Mahoney, N., Lardner, R., Molyneux, R. J., Scott, E. S., Smith, L. R., and Schoch, T. K. 2003. Phenolic and heterocyclic metabolite profiles of the grapevine pathogen Eutypa lata. Phytochemistry 64:475-484

19. Mahoney, N., Molyneux, R. J., Leverett, R. S., Schoch, T. K., Rolshausen, P. E., and Gubler, W. D. 2005. Dying-arm disease in grapevines: diagnosis of infection with Eutypa lata by metabolite analysis. J. Agric. Food Chem. 53:8148-8155.

20. Moller, W. J., and Carter, M. V. 1965. Production and dispersal of ascospores in Eutypa armeniacae. Aust. J. Biol. Sci. 18:67-80.

21. Moller, W. J., English, H., and Davis, J. R. 1966. The perithecial stage of Eutypa armeniacae in California. Plant Dis. Rep. 50:53

22. Moller, W. J., and Kasimatis, A. N. 1978. Dieback of grapevine caused by Eutypa armeniacae. Plant Dis. Rep. 62:254-258.

23. Moller, W. J., Ramos, D. E., and Hildreth, W. R. 1971. Apricot pathogen associated with Ceanothus limb dieback in California. Plant Dis. Rep. 55:1006-1008.

24. Molyneux, R. J., Mahoney, N., Bayman, P., Wong, R. Y., Meyer, K., and Irelan, N. 2002. Eutypa dieback in grapevines: differential production of acetylenic phenol metabolites by strains of Eutypa lata. J. Agric. Food Chem. 50:1393-1399.

25. Munkvold, G. P., Duthie, G. A., and Marois, J. J. 1994. Reductions in yield and vegetative growth of grapevines due to Eutypa dieback. Phytopathology 84:186-192.

26. Munkvold, G. P., and Marois, J. J. 1994. Eutypa dieback of sweet cherry and occurrence of Eutypa lata perithecia in the central valley of California. Plant Dis. 78:200-207.

27. O’Donnell, K., and Cigelnik, E. 1997. Two different intragenomic rDNA ITS2 types within a monophyletic lineage of the fungus Fusarium are nonorthologous. Mol. Phylogenet. Evol. 7:103-116.

28. Petzoldt, C. H., Sall, M. A., and Moller, W. J. 1983. Eutypa dieback of grapevines: ascospore dispersal in California. Am. J. Enol. Vitic. 34:265270.

29. Peros, J. P., and Berger, G. 1994. A rapid method to assess the aggressiveness of Eutypa lata isolates and the susceptibility of grapevine cultivars to Eutypa dieback. Agronomie 14:515-523.

30. Peros, J. P., and Berger, G. 1999. Diversity within natural progenies of the grapevine dieback fungus Eutypa lata. Curr. Genet. 36:301-309.

31. Peros, J. P., and Berger, G. 2003. Genetic structure and variation in aggressiveness in European and Australian populations of the grapevine dieback fungus, Eutypa lata. Eur. J. Plant Pathol. 109:909-919.

32. Peros, J. P., Berger, G., and Lahogue, F. 1997. Variation in pathogenicity and genetic structure in the Eutypa lata population of a single vineyard. Phytopathology 87:799-806.
33. Peros, J. P., and Larignon, P. 1998. Confirmation of random mating and indication for gene flow in the grapevine dieback fungus Eutypa lata. Vitis 37:97-98

34. Peros, J. P., This, P., Confuron Y., and Chacon, H. 1996. Comparison by isozyme and RAPD analysis of some isolates of the grapevine dieback fungus, Eutypa lata. Am. J. Enol. Vitic. 47:49-56.

35. Ramos, D. E., Moller, W. J., and English, H. 1975. Production and dispersal of ascospores of Eutypa armeniacae in California. Phytopathology 65:1364-1371.

36. Rappaz, F. 1987. Taxonomie et nomenclature des Diatrypacées à asques octosporées. Mycol. Helv. 2:285-648.

37. Rolshausen, P. E., Greve, L. C., Labavitch, J. M., Mahoney, N. E., Molyneux, R. J., and Gubler, W. D. 2008. Pathogenesis of Eutypa lata in grapevine: identification of virulence factors and biochemical characterization of cordon dieback. Phytopathology 98:222-229.

38. Rolshausen, P. E., and Gubler, W. D. 2005. Use of boron for the control of Eutypa dieback of grapevines. Plant Dis. 89:734-738.

39. Rolshausen, P. E., Mahoney, N. E., Molyneux, R. J., and Gubler, W. D. 2006. Reassessment of the species concept in Eutypa lata, the causal agent of Eutypa dieback of grapevine. Phytopathology 96:369-377.

40. Rolshausen, P. E., Trouillas, F. P, and Gubler, W. D. 2004. Identification of Eutypa lata by PCR-RFLP. Plant Dis. 88:925-929.

41. Siebert, J. B. 2001. The economic toll on vineyard. Wines Vines April:5055.

42. Sosnowski, M. R., Creaser, M. L., Wicks, T. J., Lardner, R., and Scott, E. S. 2008. Protection of grapevine pruning wounds from infection by Eutypa lata. Aust. J. Grape Wine Res. 14:134-142.

43. Sosnowski, M. R., Loschiavo, A. P., and Wicks, T. J. 2009. Managing Eutypa dieback in grapevines by spraying pruned vines with fungicide. Phytopathol. Mediterr. 48:187-188.

44. Sosnowski, M. R., Loschiavo, A. P., Wicks, T. J., and Scott, E. S. 2009. Evaluation of wound treatments to control Eutypa dieback in grapevines. Phytopathol. Mediterr. 48:184-185.

45. Stukenbrock, E. H., and McDonald, B. A. 2008. The origins of plant pathogens in agro-ecosystems. Annu. Rev. Phytopathol. 46:75-100.

46. Swofford, D. L. 1999. PAUP*. Phylogenetic Analysis Using Parsimony (*and Other Methods). Version 4.0b4a. Sinauer Associates, Sunderland, MA.

47. Taylor, J. W. 2000. Phylogenetic species recognition and species concept in fungi. Fungal Genet. Biol. 31:21-32.

48. Thompson, J. D., Higgins, D. G., and Gibson, T. J. 1994. CLUSTAL W: improving the sensitivity of progressive multiple sequence alignment through sequence weighting, position-specific gap penalties and weight matrix choice. Nucleic Acids Res. 22:4673-4680.

49. Trouillas, F. P., and Gubler, W. D. 2004. Identification and characterization of Eutypa leptoplaca, a new pathogen of grapevine in Northern California. Mycol. Res. 108:1195-1204.

50. Trouillas, F. P., Úrbez-Torres, J. R., and Gubler, W. D. Diversity of diatrypaceous fungi associated with grapevine canker diseases in California. Mycologia 102:319-336.

51. Úrbez-Torres, J. R., Leavitt, G. M., Voegel, T., and Gubler W. D. 2006. Identification and distribution of Botryosphaeria species associated with grapevines cankers in California. Plant Dis. 90:1490-503

52. Weber, E. A., Trouillas, F. P., and Gubler, W. D. 2007. Double pruning of grapevines: a cultural practice to reduce infections by Eutypa lata. Am. J. Enol. Vitic. 58:61-66.

53. White, T. J, Bruns, T., Lee, S., and Taylor, J. 1990. Amplification and direct sequencing of fungal ribosomal RNA genes for phylogenetics. Pages 315-322 in: PCR Protocols, a Guide to Methods and Applications. Academic Press, San Diego, CA. 